\title{
Assessment of the impact of adherence and other predictors during HAART on various CD4 cell responses in resource-limited settings
}

This article was published in the following Dove Press journal:

Patient Preference and Adherence

22 March 2012

Number of times this article has been viewed

\section{Danho Pascal Abrogoua ${ }^{1,2}$ \\ Brou Jerome Kablan' \\ Boua Alexis Thierry \\ Kamenan ${ }^{1,3}$ \\ Gilles Aulagner ${ }^{4}$ \\ Konan N'Guessan' \\ Christian Zohoré}

'Laboratoire de Pharmacie Clinique, Pharmacologie et Therapeutique UFR Sciences Pharmaceutiques et Biologiques, ${ }^{2}$ Laboratoire de Pharmacologie Clinique, $\mathrm{CHU}$ de Cocody, ${ }^{3}$ Service de Pharmacie, $\mathrm{CHU}$ de Cocody, Abidjan, Cote d'Ivoire, ${ }^{4}$ Service Pharmaceutique Hopital Louis Pradel, Lyon, France
Correspondence: Danho Pascal Abrogoua 22 BP I397 Abidjan, Cote d'Ivoire

Tel +22507949478

Email abrogouadp@yahoo.fr
Objective: The aim of this study was to quantify, by modeling, the impact of significant predictors on CD4 cell response during antiretroviral therapy in a resource-limited setting.

Methods: Modeling was used to determine which antiretroviral therapy response predictors (baseline CD4 cell count, clinical state, age, and adherence) significantly influence immunological response in terms of CD4 cell gain compared to a reference value at different periods of monitoring.

Results: At 6 months, CD4 cell response was significantly influenced by baseline CD4 count alone. The probability of no increase in CD4 cells was 2.6 higher in patients with a baseline CD4 cell count of $\geq 200 / \mathrm{mm}^{3}$. At 12 months, CD4 cell response was significantly influenced by both baseline CD4 cell count and adherence. The probability of no increase in CD4 cells was three times higher in patients with a baseline CD4 cell count of $\geq 200 / \mathrm{mm}^{3}$ and 0.15 times lower with adherent patients. At 18 months, CD4 cell response was also significantly influenced by both baseline CD4 cell count and adherence. The probability of no increase in CD4 cells was 5.1 times higher in patients with a baseline CD4 cell count of $\geq 200 / \mathrm{mm}^{3}$ and 0.28 times lower with adherent patients. At 24 months, optimal CD4 cell response was significantly influenced by adherence alone. Adherence increased the probability (by 5.8) of an optimal increase in CD4 cells. Age and baseline clinical state had no significant influence on immunological response.

Conclusion: The relationship between adherence and CD4 cell response was the most significant compared to that of baseline CD4 cell count. Counseling before initiation of treatment and educational therapy during follow-up must always help to strengthen adherence and optimize the efficiency of antiretroviral therapy in a resource-limited setting.

Keywords: antiretroviral therapy, CD4 cells response, adherence, predictors, modeling, Abidjan

\section{Introduction}

According to a United Nations report on human immunodeficiency virus (HIV)/ acquired immune deficiency syndrome (AIDS) in 2009, sub-Saharan Africa still bears an inordinate share of the HIV global burden. ${ }^{1}$ Although the rate of new HIV infections has decreased, the total number of people living with HIV/AIDS (PLWHAs) continues to rise. ${ }^{1}$ A CD4 cell count is recommended in practice for developing countries to monitor PLWHAs as it enables better decisions on the appropriate time to begin highly active antiretroviral therapy (HAART). CD4 cell count is also essential in monitoring the treatment, and it remains the best factor for predicting the occurrence of HIV-related complications. ${ }^{2}$ However, there is risk in only using CD4 cell count in patients on antiretroviral therapy (ART) without virological monitoring in 
resource-limited settings. While most predictors of ART are known, their quantitative impact on the field immunological response is not. For the present study, immunological response was quantified by an increase in CD4 cells compared to the baseline CD4 cell count.

According to the World Health Organization, the definitions of clinical, immunological, and virological failure currently used in different settings represent different biological endpoints. It is not clear which criteria are optimal, as either individual measures or a combination of measures. ${ }^{3}$ Several international recommendations based on clinical studies found thresholds close to an optimal CD4 cell gain that could be achieved in 6 months or annually during an effective ART. The first 6 months of ART is a critical period for the future and should be given special attention. ${ }^{4}$ Immunological response failure can be described by a CD4 cell gain of $<100 / \mathrm{mm}^{3}$ from the initiation of treatment, ${ }^{5}$ and it is often associated with a poor immune recovery (CD4 cell count $<200 / \mathrm{mm}^{3}$ ). ${ }^{3}$ Functional immunological failure is defined by The World Health Organization among other acceptable definitions - as a CD4 cell count of $<100$ cells $/ \mathrm{mm}^{3}$ after 6 months of treatment or a return to the level of CD4 cell count before the start of treatment (or a fall below this level) after 6 months of treatment. The immunological response in an effective ART is judged by an increase in CD4 cells of $150-200 / \mathrm{mm}^{3}$ in the first year and then more progressively. ${ }^{4}$ An adequate immunological response for most patients under treatment is defined as an increase in CD4 cells of $50-150 / \mathrm{mm}^{3}$ per year, generally with quicker response during the first 3 months. ${ }^{6}$ Subsequent increases in patients with good virological control showed an average increase of about $50-100$ cells $/ \mathrm{mm}^{3}$ per year for subsequent years until a steady level is reached. ${ }^{7}$

A CD4 cell count equal to $200 / \mathrm{mm}^{3}$ is the key threshold value below which the risk of disease progression is increased significantly. ${ }^{3}$ Although it is never too late to start ART, it is better to start before the CD4 cell count drops below $200 / \mathrm{mm}^{3}{ }^{3}$ Data from several cohorts of asymptomatic patients, for example, converge to show that disease progression is accelerated in those of them who begin ART when their CD4 cell count is $<200 / \mathrm{mm}^{3}{ }^{3-12}$ This is also supported by long-term data from several observational studies evaluating early ART $\left(>200\right.$ cells $\left./ \mathrm{mm}^{3}\right)$ compared to delayed treatment $\left(<200\right.$ cells $\left./ \mathrm{mm}^{3}\right) .{ }^{13-16}$ Several clinical trials have also demonstrated the benefit of the introduction of ART, both in terms of survival and in reducing disease progression in patients with CD4 cell counts of $<200 / \mathrm{mm}^{3} .{ }^{17}$ In advanced disease (AIDS stage or CD4 cell count of $<200 / \mathrm{mm}^{3}$ ), life expectancy is shorter, justifying the recommendation of ART at this stage. ${ }^{4}$ The consequences of incomplete adherence of ART in raising the morbidity, mortality, and risk of drug resistance have long since been highlighted. ${ }^{18,19}$ Treatment success is related to a very high level of adherence at the initiation of treatment, but also over time. A review of the effectiveness of ART in 24 studies related to interventions about adherence and published between 1996 and 2004, showed the best results were obtained when these interventions were targeted to people with poor adherence. ${ }^{20}$ Adherence remains a major concern in optimizing the response of ART in both industrialized countries and in developing countries. Age is also a risk factor for delayed treatment and less response to treatment. The increase of CD4 cells is usually slower and incomplete in the elderly and/or in those whose immunosuppression has been profound and prolonged. ${ }^{3}$ The risk of progression is more rapid in patients starting treatment after 50 years of age. ${ }^{10}$ Patients aged $\geq 50$ years have a lower immunological response to treatment despite a good virological response. ${ }^{18,21}$

Some studies devoted to modeling ART response from taxonomy of CD4 count trajectories revealed several determinants influencing the field immunological response in Cote d'Ivoire, ${ }^{22-24}$ which included age, clinical stage, baseline CD4 cell count, and adherence. These parameters are not exhaustive, but are the predictors that were considered in the present study. The extent of CD4 cell count recovery varies during ART, despite suppression of the viral load. The clinical implication of this conundrum is important because suboptimal CD4 cell count recovery is associated with an increased risk of disease progression. ${ }^{25-29}$

In the absence of viral load in routine management of PLWHAs during ART in resource-limited settings, it's important to analyze determinants of immunological response. As mentioned previously, the real quantitative impact of ART response predictors on the field immunological response has not been established. Therefore it's important to evaluate the real quantitative impact of these predictors on various CD4 cells responses in terms of optimal, suboptimal, or absence of CD4 cell increase. Cote d'Ivoire modeling studies in bioclinical and therapeutic monitoring of patients are rare. The modeling stage in clinical research is fundamental because the mathematical models can be used to summarize the situation and try to supply rigorous (ie, statistically significant) answers, which can ensure the efficiency of ART in resource-limited countries. Therefore, the aim of the present study was to use modeling to determine which ART response predictors (baseline CD4 cell count, 
clinical state, age, and adherence) significantly influence immunological response in terms of CD4 cell gain compared to a reference value at different periods of monitoring in a resource-limited setting.

\section{Methods}

\section{Patients and biomedical data}

The biomedical data underlying this model are from a longitudinal observational database of bioclinical and therapeutic monitoring of outpatients on antiretroviral therapy. This study is consistent with the ethical aspects related to patients during their follow-up with a noninvasive method for the collection of medical and therapeutic data. Data are from the routine monitoring of patients with prior approval from the administrative health authority. The observational databases are suitable for any modeling. Indeed, these databases showing long-term monitoring of patients has the undisputed advantage of measuring the reality of the disease, with consideration of patient care in routine clinical practice. This observational study was conducted in clinical centers accredited in the care of PLWHAs in Abidjan: Unit of Ambulatory Care and Advice (USAC) and the Center for Integrated Bioclinical Research of Abidjan (CIRBA). This clinical study was carried out on HIV-infected outpatients, which included HIV-positive men and women (irrespective of HIV type) aged $\geq 15$ years who were antiretroviral-naive (had no history of antiretroviral use) and were prescribed triple drug antiretroviral therapy at enrolment in the drug treatment program between 2007 and 2008. Study subjects were followed during 24 months of therapy by their regular physician in routine clinical practice. According to the immunological and clinical criteria (Centers for Disease Control and Prevention [CDC] classification 1993) $)^{30}$ and eligibility to antiretroviral therapy for adolescents and adults in Cote d'Ivoire, ${ }^{31}$ asymptomatic patients with a CD4 cell count of $<200 / \mathrm{mm}^{3}$, symptomatic patients (CDC stage B) with a CD4 cell count of $<350 / \mathrm{mm}^{3}$, and AIDS-symptomatic patients (CDC stage $\mathrm{C}$ ) irrespective of CD4 cell count were considered. The follow-up period was limited to 24 months. Adherence was assessed every 3 months with low-cost methods (interviewing and keeping of medical appointments - including appointments at the pharmacy to replenish antiretroviral drugs) in a resourcelimited setting. Treatment adherence was assessed by the patients' regular physician. A general analysis on the review of access to ART in Cote d'Ivoire confirmed that the most common methods of assessing adherence are the keeping of appointments and interviewing patients during consultations or prescription refills at the pharmacy. ${ }^{32} \mathrm{CD} 4$ cell counts were determined by flow cytometry (FACSCalibur; Becton Dickinson, Franklin Lakes, NJ). A baseline CD4 cell count not only guides the decision on when to initiate ART but is also essential if CD4 cell counts are to be used to monitor ART, particularly in resource-limited settings. Outpatients eligible for ART without a baseline CD4 cell count were not included in the study. Subjects who had at least four CD4 cell count measurements after 2 years of HAART initiation were included.

\section{Multivariate logistic regression model}

Routine monitoring of post-HAART CD4 cell counts is recommended every 6 months in resource-limited settings. Therefore, the post-HAART follow-up periods selected were: M6 (at 6 months), M12 (at 12 months), M18 (at 18 months), and M24 (at 24 months). CD4 cell gain was determined from the baseline CD4 cell count at M0 (prior to initiation of treatment). Baseline CD4 cell count was defined as the pre-HAART measurement of CD4 cell count after enrolment of the patient in the drug treatment program. CD4 cell gain for each patient was determined as the difference between CD4 cell count at each post-HAART follow-up period and the individual baseline CD4 cell count. The general equation of the model was:

$$
\mathrm{R}(\mathrm{t})=\beta_{0}+\beta_{1} \operatorname{clin}+\beta_{2} \mathrm{CD} 4+\beta_{3} \mathrm{age}+\beta_{4} \operatorname{adher}(\mathrm{t})+\varepsilon,(1)
$$

where $\mathrm{R}(\mathrm{t})$ is the immunological response within the monitoring period $t$, clin is the baseline CDC clinical stage, CD4 is the baseline CD4 cell count, age is the patient's age at initiation of treatment, adher $(\mathrm{t})$ is adherence at the monitoring period $t$, and $\varepsilon$ is the error term. The equation is a model on immunological response in terms of CD4 cell gain dependent on adherence and other predictors of ART response. The strength of relationship between these parameters and the antiretroviral response was estimated (coefficients estimated by the model are mathematically related to the odds ratio). A multinomial logistic regression was conducted using Stata ${ }^{\circledR}$ (v 9; StataCorp LP, College Station, TX). The dependent variable is the immunological response to ART within monitoring period $\mathrm{t}(\mathrm{R}[\mathrm{t}])$. The regression model was multinomial because three modalities for $R(t)$ were chosen: $\mathrm{R}_{2}$ (coded two), optimal immunological response; $\mathrm{R}_{1}$ (coded one), suboptimal immunological response; and $\mathrm{R}_{0}$ (coded zero), stabilization or decrease of CD4 cell count compared to the baseline value. A reference value of CD4 cell gain was chosen at each follow-up period. With an optimal immunological response, CD4 cell gain must be higher than this reference value. A suboptimal immunological response 
was equivalent to a CD4 cell gain below the reference value, but not zero. At each follow-up period, a type of immunological response was considered by the software as a reference. Each explanatory variable as an ART response predictor had two modalities: compared to a good immunological response, the first modality was coded zero (unfavorable) and the second was coded one (favorable). The significance threshold for the multivariate analysis was 5\% (ie, $P<0.05$ ). Descriptions of codes, values, and modalities of the different variables are presented in Tables 1 and 2 .

\section{Results}

\section{Baseline characteristics and adherence}

The study was based on a total of 403 individuals (160 men and 243 women). At baseline the median age was 40 years (interquartile range: 33-47). Patients eligible for treatment were mainly symptomatic (CDC stage B) with a CD4 cell count of $<350 / \mathrm{mm}^{3}$. A baseline CD4 cell count of $<200 / \mathrm{mm}^{3}$ was higher among patients with a median of 137/ $\mathrm{mm}^{3}$ (interquartile range: 64-211). The antiretroviral regimen was predominantly composed of an association between two nucleoside reverse transcriptase inhibitors plus one nonnucleoside reverse transcriptase inhibitor: of the 403 study subjects, 374 (92.8\%) patients initiated therapy with a nonnucleoside reverse transcriptase inhibitor-based regimen. Of those 374 patients, 240 (64.17\%) used nevirapine and $134(35.83 \%)$ used efavirenz. Adherence was lowest at M24. All the baseline characteristics of patients are presented in Table 3.

\section{Multinomial logistic regression analysis}

The model was globally significant at M6 $(P=0.04), \mathrm{M} 12$ $(P=0.0053), \mathrm{M} 18(P=0.0008)$, and M24 $(P<0.0001)$. The explanatory variables combined influence the immunological response at the different monitoring periods. However, some observations may influence the model alone. Therefore, in order to judge the quality of the model fit to data collected, it was important to analyze remainders in order to detect poorly modeled observations. The analysis showed that these various observations did not significantly affect the model.

\section{Quantitative impact of significant predictors on various CD4 cell} response at different periods of follow-up At M6, the model $(P=0.04)$ and the coefficient of baseline CD4 cell count $(P=0.001)$ were significant. Baseline CD4 cell count significantly influenced the ART response. The equation of the immunological response was:

$$
\operatorname{Ln}\left[\mathrm{P}\left(\mathrm{R}_{0}\right) / \mathrm{P}\left(\mathrm{R}_{2}\right)\right]=-1.3+0.94 \times \mathrm{CD} 4
$$

The probability of having no CD4 cell gain compared to a gain of $\geq 100 / \mathrm{mm}^{3}$ was influenced at M6 by the baseline CD4 cell count, ie, it was 2.6 higher in patients with a baseline CD4 cell count of $\geq 200 / \mathrm{mm}^{3}$ than those with a baseline CD4 cell count of $<200 / \mathrm{mm}^{3}$ at M6 (Table 4 ).

At M12, the model $(P=0.0053)$ and the coefficients of baseline CD4 cell count $(P=0.003)$ and adherence $(P<0.001)$ were significant. Adherence and baseline CD4 cell count significantly influenced ART response. The equation of the immunological response was:

$$
\operatorname{Ln}\left[\mathrm{P}\left(\mathrm{R}_{0}\right) / \mathrm{P}\left(\mathrm{R}_{2}\right)\right]=0.06+1.1 \times \mathrm{CD} 4-1.90 \times \operatorname{adher}(\mathrm{M} 12)
$$

The probability of having no CD4 cell gain compared to a gain of $\geq 150 / \mathrm{mm}^{3}$ was influenced at M12 by both baseline CD4 cell count and adherence, ie, it was three times higher in patients with a baseline CD4 cell count of $\geq 200 / \mathrm{mm}^{3}$ than those with a baseline CD4 cell count of $<200 / \mathrm{mm}^{3}$ and 0.15 times less higher with adherent patients than with nonadherent ones at M12 (Table 4).

At M18, the model $(P=0.0008)$ and the coefficients of baseline CD4 cell count $(P<0.01)$ and adherence $(P=0.022)$ were significant. Adherence and baseline CD4

\begin{tabular}{|c|c|c|c|}
\hline \multirow{2}{*}{$\begin{array}{l}\text { Follow-up } \\
\text { period }\end{array}$} & \multicolumn{3}{|c|}{ Expression and code of immunological response } \\
\hline & $\begin{array}{l}\text { Optimal immunological } \\
\text { response } \\
\mathbf{R}_{2}=2\end{array}$ & $\begin{array}{l}\text { Suboptimal immunological } \\
\text { response } \\
\mathbf{R}_{\mathbf{I}}=\mathbf{I}\end{array}$ & $\begin{array}{l}\text { Stabilization or decrease of CD4 cell } \\
\text { count compared to the baseline value } \\
\mathbf{R}_{0}=0\end{array}$ \\
\hline M6 & CD4 cell gain $\geq 100 / \mathrm{mm}^{3}$ & CD4 cell gain $<100 / \mathrm{mm}^{3}$ & Absence of CD4 cell gain \\
\hline MI2 & CD4 cell gain $\geq 150 / \mathrm{mm}^{3}$ & CD4 cell gain $<150 / \mathrm{mm}^{3}$ & Absence of CD4 cell gain \\
\hline MI8 & CD4 cell gain $\geq 200 / \mathrm{mm}^{3}$ & CD4 cell gain $<200 / \mathrm{mm}^{3}$ & Absence of CD4 cell gain \\
\hline M24 & CD4 cell gain $\geq 250 / \mathrm{mm}^{3}$ & CD4 cell gain $<250 / \mathrm{mm}^{3}$ & Absence of CD4 cell gain \\
\hline
\end{tabular}

Table I Codes, values, and description of dependent variables at different periods of medical follow-up

Abbreviations: M6, 6 months; MI2, 12 months; MI8, 18 months; M24, 24 months. 
Table 2 Codes, values, and description of explanatory variables

\begin{tabular}{ll}
\hline Explanatory variables & Modality and codes \\
\hline Baseline CDC clinical stage & Stage C: 0 \\
& Stages A and B: I \\
Baseline CD4 cell count & $<200 / \mathrm{mm}^{3}: 0$ \\
& $\geq 200 / \mathrm{mm}^{3}:$ I \\
Age at treatment initiation & $>50$ years: 0 \\
& $\leq 50$ years: I \\
Adherence at different periods of medical & Incomplete adherence: 0 \\
follow-up & Good adherence: I \\
\hline
\end{tabular}

Abbreviation: CDC, Centers for Disease Control and Prevention.

cell count significantly influenced ART response. The equation of the immunological response was:

$$
\operatorname{Ln}\left[\mathrm{P}\left(\mathrm{R}_{0}\right) / \mathrm{P}\left(\mathrm{R}_{1}\right)\right]=-0.95+1.63 \times \mathrm{CD} 4-1.27 \times \operatorname{adher}(\mathrm{M} 18)
$$

The probability of having no CD4 cell gain compared to a gain of $<200 / \mathrm{mm}^{3}$ at M18 was influenced by both baseline CD4 cell count and adherence, ie, it was 5.1 times higher in patients with a baseline CD4 cell count of $\geq 200 / \mathrm{mm}^{3}$ than in those with a baseline CD4 cell count of $<200 / \mathrm{mm}^{3}$ and 0.28 times lower with adherent patients than with nonadherent ones at M18 (Table 5).

At M24, adherence and baseline CD4 cell count significantly influenced ART response. The model $(P<0.0001)$ and the coefficients of baseline CD4 cell count $(P=0.037)$ and adherence $(P=0.023)$ were significant in modeling the response $\mathrm{R}_{0}$ in relation to response $\mathrm{R}_{1}$. The equation of the immunological response was:

$\operatorname{Ln}\left[\mathrm{P}\left(\mathrm{R}_{0}\right) / \mathrm{P}\left(\mathrm{R}_{1}\right)\right]=-0.90+0.99 \times \mathrm{CD} 4-1.12 \times \operatorname{adher}(\mathrm{M} 24)$

The probability of having no CD4 cell gain compared to a gain of $<250 / \mathrm{mm}^{3}$ was influenced by both baseline CD4 cell count and adherence at M24. Moreover, by modeling the response $\mathrm{R}_{2}$ in relation to response $\mathrm{R}_{1}$, the model remained significant $(P<0.0001)$, but only the coefficient of adherence was significant $(P<0.001)$. The equation of the immunological response was then:

$$
\operatorname{Ln}\left[\mathrm{P}\left(\mathrm{R}_{2}\right) / \mathrm{P}\left(\mathrm{R}_{1}\right)\right]=1.98+1.76 \times \operatorname{adher}(\mathrm{M} 24)
$$

The probability of having a CD4 cell gain of $\geq 250 / \mathrm{mm}^{3}$ compared to a gain of $<250 / \mathrm{mm}^{3}$ was only influenced by adherence at M24. The likelihood of having no CD4 cell gain compared to a gain of $<250 / \mathrm{mm}^{3}$ was 2.7 times higher in

\begin{tabular}{|c|c|}
\hline \multicolumn{2}{|l|}{ Age at treatment initiation } \\
\hline Median (IQR) & $40(33-47)$ \\
\hline$>50$ years & $61(15.14)$ \\
\hline$\leq 50$ years & $342(84.86)$ \\
\hline Female & $243(60.3)$ \\
\hline \multicolumn{2}{|l|}{ HIV type } \\
\hline HIVI & $377(93.5)$ \\
\hline HIV2 & II (2.7) \\
\hline HIV dual & $15(3.7)$ \\
\hline Karnofsky score median (IQR) & $90(90-100)$ \\
\hline \multicolumn{2}{|l|}{ Groups of eligible patients for ART } \\
\hline $\begin{array}{l}\text { Asymptomatic patients with CD } 4 \text { cell count } \\
\text { of }<200 / \mathrm{mm}^{3}\end{array}$ & $31(7.69)$ \\
\hline $\begin{array}{l}\text { Symptomatic patients (CDC stage B) with CD4 } \\
\text { cell count of }<350 / \mathrm{mm}^{3}\end{array}$ & $273(67.74)$ \\
\hline $\begin{array}{l}\text { Symptomatic patients (CDC stage } C \text { ) irrespective } \\
\text { of CD4 cell count }\end{array}$ & $99(24.57)$ \\
\hline \multicolumn{2}{|l|}{ Baseline CDC clinical stage } \\
\hline Stages $A$ and $B$ & $304(75.43)$ \\
\hline Stage C & $99(24.56)$ \\
\hline \multicolumn{2}{|l|}{ Baseline CD4 cell count $/ \mathrm{mm}^{3}$} \\
\hline Median (IQR) & $137(64-2 \mid 1)$ \\
\hline$<200$ & $291(72.2)$ \\
\hline$\geq 200$ & $112(27.8)$ \\
\hline Presence of opportunistic infections & $207(5 \mid .4)$ \\
\hline \multicolumn{2}{|l|}{ ART regimens } \\
\hline NNRTI-based regimen & $374(92.8)$ \\
\hline PI-based regimen & $23(5.6)$ \\
\hline 3 NRTIs regimen & $6(1.5)$ \\
\hline Patients with cotrimoxazole prophylaxis & $377(93.5)$ \\
\hline \multicolumn{2}{|l|}{ Good adherence to ART } \\
\hline M6 & $383(95)$ \\
\hline MI2 & $364(90.32)$ \\
\hline MI8 & $375(93)$ \\
\hline M24 & $350(86.8)$ \\
\hline
\end{tabular}

Table 3 Patients' baseline characteristics and adherence

Note: Data presented as $n(\%)$ unless otherwise stated.

Abbreviations: ART, antiretroviral therapy; CDC, Centers for Disease Control and Prevention; HIV, human immunodeficiency virus; IQR, interquartile range; M6, 6 months; MI2, 12 months; MI8, 18 months; M24, 24 months; NRTI, nucleoside reverse transcriptase inhibitor; NNRTI, nonnucleoside reverse transcriptase inhibitor; PI, protease inhibitor.

patients with a baseline CD4 cell count of $\geq 200 / \mathrm{mm}^{3}$ than those with a baseline CD4 cell count of $<200 / \mathrm{mm}^{3}$ and 0.3 times lower with adherent patients than with nonadherent ones. Adherence alone $(P<0.001)$ increased the probability (by 5.8) of having a CD4 cell gain of $\geq 250 / \mathrm{mm}^{3}$ compared to a gain of $<250 / \mathrm{mm}^{3}$ (Table 5 ).

\section{Discussion}

The ultimate goal of HAART is the reconstitution of the immune system by viral suppression and obtaining a CD4 cell count that protects optimally against opportunistic infections and HIV-related cancers. ${ }^{33}$ In patients with a sustained reduction in viral load, CD4 cell counts increase for at least 
Table 4 Odds ratio representing relative risks of response $R_{0}$ or $R_{1}$ compared to response $R_{2}$ at 6-month and 12 -month follow-up period

\begin{tabular}{|c|c|c|c|c|c|c|c|c|}
\hline \multirow{2}{*}{$\begin{array}{l}\text { Follow-up } \\
\text { period }\end{array}$} & \multirow[t]{2}{*}{ Favorable variables } & \multirow[t]{2}{*}{ Reference } & \multicolumn{3}{|c|}{ Response $\mathbf{R}_{0}{ }^{a}$} & \multicolumn{3}{|c|}{ Response $\mathbf{R}_{\mathbf{1}}{ }^{a}$} \\
\hline & & & OR & $95 \% \mathrm{Cl}$ & $P$ & OR & $95 \% \mathrm{Cl}$ & $P$ \\
\hline \multirow[t]{5}{*}{ M6 } & Age $\leq 50$ years & Age $>50$ years & 1.28 & $0.57-2.86$ & 0.542 & $\mathrm{I} .44$ & $0.76-2.72$ & 0.262 \\
\hline & Stages A or B & Stage C & 0.91 & $0.47-1.76$ & 0.782 & 0.98 & $0.58-1.63$ & 0.932 \\
\hline & Baseline CD4 cell count & Baseline CD4 cell count & & & & & & \\
\hline & of $\geq 200 / \mathrm{mm}^{3}$ & of $<200 / \mathrm{mm}^{3}$ & 2.57 & $1.44-4.57$ & 0.001 & 0.78 & $0.46-1.32$ & 0.350 \\
\hline & Good adherence & Incomplete adherence & 0.70 & $0.20-2.4 I$ & 0.576 & 0.76 & $0.28-2.11$ & 0.603 \\
\hline \multirow[t]{5}{*}{$\mathrm{M} 12$} & Age $\leq 50$ years & Age $>50$ years & 0.76 & $0.30-1.94$ & 0.568 & 1.12 & $0.62-2.02$ & 0.709 \\
\hline & Stages A or B & Stage C & 0.76 & $0.35-1.69$ & 0.509 & 1.08 & $0.66-1.77$ & 0.747 \\
\hline & Baseline CD4 cell count & Baseline CD4 cell count & & & & & & \\
\hline & of $\geq 200 / \mathrm{mm}^{3}$ & of $<200 / \mathrm{mm}^{3}$ & 3 & $1.45-6.26$ & 0.003 & 1.20 & $0.75-1.94$ & 0.446 \\
\hline & Good adherence & Incomplete adherence & 0.15 & $0.06-0.39$ & $<0.001$ & 0.53 & $0.24-1.14$ & 0.105 \\
\hline
\end{tabular}

Notes: ${ }^{\text {Responses }} \mathrm{R}_{0}$ and $\mathrm{R}_{1}$ were compared to response $\mathrm{R}_{2} ; P<0.05$ was considered significant.

Abbreviations: $\mathrm{Cl}$, confidence interval; OR, odds ratio; $\mathrm{R}_{0}$, stabilization or decrease of CD4 cell count compared to the baseline value; $\mathrm{R}_{1}$, suboptimal immunological response; $R_{2}$, optimal immunological response.

3-5 years after initiation of treatment. The initial increase in CD4 cells within 3-6 months is usually rapid and is followed by a second phase of slowing growth rates approaching a stable CD4 cell count at 4-6 years. ${ }^{7,34}$ Other authors have noted a significant increase in $\mathrm{CD} 4$ cell count during the first 2 years after starting HAART, followed by stabilization between $2-3.5$ years. ${ }^{35}$ This suggests the existence of a change in slope of the trajectory of CD4 cell count at about 2 years after starting treatment, reaching a straight line.

The present study of the determinants of immunological response was significant because, according to the studies mentioned above, the first 2 years are critical for obtaining a substantial increase in CD4 cell count after initiation of treatment. Using a logistic regression model, baseline CD4 cell count and adherence were identified as factors significantly associated with immunological response during the first 24 months of treatment. The results showed that a substantial increase in CD4 cells during ART was most notable in patients with a weaker baseline CD4 cell count $\left(<200 / \mathrm{mm}^{3}\right)$. However, this does not mean that the therapeutic response was not positive in patients with baseline CD4 cell counts that were $\geq 200 / \mathrm{mm}^{3}$; but obtaining the optimal CD4 cell gain was less likely. The probability of having no CD4 cell gain was progressively lower over time among adherent patients. At M24, obtaining the optimal CD4 cell gain was almost six times higher among adherent patients in Abidjan compared to a suboptimal gain of CD4 cells. Based on the present analysis, it can be considered that a patient who begins ART with a lower baseline CD4 cell count $\left(<200 / \mathrm{mm}^{3}\right)$ is able to obtain the optimal CD4 cell gain, of course by maintaining good adherence throughout the first 24 months of treatment. Patients in the present study with a

Table 5 Odds ratio representing relative risks of response $R_{0}$ or $R_{2}$ compared to response $R_{1}$ at 18-month and 24-month follow-up period

\begin{tabular}{|c|c|c|c|c|c|c|c|c|}
\hline \multirow{2}{*}{$\begin{array}{l}\text { Follow-up } \\
\text { period }\end{array}$} & \multirow[t]{2}{*}{ Favorable variables } & \multirow[t]{2}{*}{ Reference } & \multicolumn{3}{|c|}{ Response $\mathbf{R}_{0}{ }^{a}$} & \multicolumn{3}{|c|}{ Response $\mathbf{R}_{2}{ }^{a}$} \\
\hline & & & OR & $95 \% \mathrm{CI}$ & $P$ & OR & $95 \% \mathrm{Cl}$ & $\boldsymbol{P}$ \\
\hline \multirow[t]{5}{*}{ MI8 } & Age $\leq 50$ years & Age $>50$ years & 0.91 & $0.31-2.69$ & 0.867 & 1.19 & $0.67-2.12$ & 0.550 \\
\hline & Stages A or B & Stage C & 0.53 & $0.22-1.29$ & 0.16 & 0.94 & $0.58-|.5|$ & 0.794 \\
\hline & Baseline CD4 cell count & Baseline CD4 cell count & & & & & & \\
\hline & of $\geq 200 / \mathrm{mm}^{3}$ & of $<200 / \mathrm{mm}^{3}$ & 5.14 & $2.22-11.89$ & $<0.001$ & 1.14 & $0.7 I-I .82$ & 0.587 \\
\hline & Good adherence & Incomplete adherence & 0.28 & $0.09-0.83$ & 0.022 & 2.44 & $0.93-6.38$ & 0.070 \\
\hline \multirow[t]{5}{*}{ M24 } & Age $\leq 50$ years & Age $>50$ years & 0.53 & $0.17-1.62$ & 0.267 & 0.97 & $0.54-1.76$ & 0.931 \\
\hline & Stages A or B & Stage $C$ & 0.45 & $0.17-1.19$ & 0.107 & 0.96 & $0.58-1.58$ & 0.873 \\
\hline & Baseline CD4 cell count & Baseline CD4 cell count & & & & & & \\
\hline & of $\geq 200 / \mathrm{mm}^{3}$ & of $<200 / \mathrm{mm}^{3}$ & 2.71 & $1.06-6.94$ & 0.037 & 0.82 & $0.50-1.32$ & 0.413 \\
\hline & Good adherence & Incomplete adherence & 0.32 & $0.12-0.86$ & 0.023 & 5.82 & $2.24-15.14$ & $<0.001$ \\
\hline
\end{tabular}

Notes: aResponses $R_{0}$ and $R_{2}$ were compared to response $R_{1} ; P<0.05$ was considered significant.

Abbreviations: $\mathrm{Cl}$, confidence interval; $\mathrm{OR}$, odds ratio; $\mathrm{R}_{0}$, stabilization or decrease of $C D 4$ cell count compared to the baseline value; $\mathrm{R}_{\mathrm{l}}$, suboptimal immunological response; $\mathrm{R}_{2}$, optimal immunological response. 
higher baseline CD4 cell count $\left(\geq 200 / \mathrm{mm}^{3}\right)$ had a relatively lower CD4 cell gain. It has been found in previous studies that patients with a significant increase in CD4 cell count in the preceding period had a smaller increase in the following period and vice versa, suggesting a manifestation of regression toward the mean and a ceiling effect for patients approaching the normal range of CD4 cell count. ${ }^{33}$ These results are similar to those reported by other studies in Africa, where patients with low CD4 cell counts had a high level of increase in CD4 cells. ${ }^{36,37}$

At M6, the baseline CD4 cell count was the only variable significantly correlated with immunological response. Kitahata et al noted improved outcomes 6 months after initiation of HAART at all levels of baseline CD4 cell count; ${ }^{38}$ but in the present study, patients with a baseline CD4 cell count of $\geq 200 / \mathrm{mm}^{3}$ had a stabilized or decreased CD4 cell count at M6 and they were, therefore, less likely to obtain the optimal CD4 cell gain. However, knowing that the baseline CD4 cell count may correspond to relatively high values, the immunological response may be considered positive if the CD4 cell count varies slightly or stabilizes at relatively high values. Since the majority of patients in Cote d'Ivoire start treatment with a relatively low CD4 cell count $\left(<350 / \mathrm{mm}^{3}\right)$ or at an advanced stage, it is important, nonetheless, to aim for an optimal CD4 cell gain in the first critical months of ART. Many AIDS-defining events occur in the first 6 months. ${ }^{39-41}$ In the present study, suboptimal CD4 cell gain was below $100 / \mathrm{mm}^{3}$ at M6. Other studies saw a $<50 / \mathrm{mm}^{3}$ increase in CD4 cell count after 6 months of ART as suboptimal. ${ }^{36,37,42,43}$ It has been shown in an urban cohort on ART in sub-Saharan Africa that the majority of patients with a suboptimal CD4 cell gain after 6 months still showed a suboptimal CD4 cell gain at 12 months despite supported viral suppression. ${ }^{37} \mathrm{As}$ patients with a suboptimal gain of $\mathrm{CD} 4$ cells at 6 months are likely to maintain the phenomenon, they may need to evaluate the recovery of immune function, especially in Africa where there is an increased risk of opportunistic infections. It is possible that $\mathrm{CD} 4$ cells do not recover both in optimum rate and function that is required for activation of T-lymphocytes in Africans due to frequent infections by various endemic pathogens in the region. ${ }^{446}$

At M12, baseline CD4 count and adherence were the two variables significantly correlated with immunological response. The interpretation is identical to that of M6 with respect to the relationship between a baseline $\mathrm{CD} 4$ cell count of $\geq 200 / \mathrm{mm}^{3}$ and the absence of optimal CD4 cell gain. But would it make sense to compare this finding to a lower adherence of patients with a high baseline CD4 cell count? A lower baseline CD4 cell count and prior diagnosis of AIDS have been previously associated with better adherence. ${ }^{47}$ Others have also found that advanced stage was associated with increased adherence of treatment, ${ }^{48}$ while others have reported an inverse relationship ${ }^{49}$ or no association with CD4 cell count. ${ }^{50}$

At M18 and M24, absence of CD4 cell gain was correlated with a baseline CD4 cell count of $\geq 200 / \mathrm{mm}^{3}$. And more importantly, this lack of CD4 cell gain was compared to obtaining a suboptimal CD4 cell gain, suggesting that obtaining the optimal CD4 cell gain is even less likely for patients with a relatively high baseline CD4 cell count $\left(\geq 200 / \mathrm{mm}^{3}\right)$ at M18 and M24. Dragsted et al, using the EuroSIDA cohort, studied predictors of immunological failure after initial response to HAART with patients who achieved a CD4 cell gain of $>100 / \mathrm{mm}^{3}$ between $6-12$ months. ${ }^{51}$ Among the three factors significantly associated with the occurrence of immunological failure in their study, there appeared a higher number of CD4 cell counts before treatment. By defining their immunological failure as the occurrence of a CD4 cell count inferior to or the same value as before treatment, this confirms, as in the present study, the correlation of the absence of optimal CD4 cell gain with a higher baseline CD4 cell count. This study had the assumption that when CD4 cell count was well above $200 / \mathrm{mm}^{3}$, the threshold of decline in CD4 cell count was higher and the clinician was not prompted to change treatment quickly for fear of recurrence of profound immune deficiency. This was confirmed by the fact that changes in treatment occurred prematurely in patients whose CD4 cell counts were lower before the treatment. ${ }^{51}$ In another study, a high baseline CD4 cell count was also associated with the occurrence of immunological failure. ${ }^{52}$ Wu et al reported on the relationships of baseline indices and virological responses to multiple CD4 cell kinetic patterns. ${ }^{53}$ They observed a negative relationship between baseline CD4 cell count and the magnitude of CD4 cell restoration. Hill et al had earlier observed that discordant CD4 cell responses to HAART were significantly more common in patients with higher baseline $\mathrm{CD} 4$ cell counts. ${ }^{54}$

At M24, good adherence was strongly and uniquely associated with obtaining the optimal CD4 cell gain $\left(\geq 250 / \mathrm{mm}^{3}\right)$ compared with a suboptimal CD4 cell gain $\left(<250 / \mathrm{mm}^{3}\right)$. Other authors considered a suboptimal CD4 cell gain as less than $200 / \mathrm{mm}^{3}$ after 24 months. ${ }^{37}$ Kulkarni et al sought to determine whether baseline CD4 cell count also influenced immune reconstitution as measured by $\mathrm{CD} 4$ cell counts 
during HAART. ${ }^{55}$ They defined baseline CD4 cell count as the first CD4 cell count measurement after diagnosis of HIV infection, while it was defined in the present study as the pre-HAART measurement of CD4 cell count. Kulkarni et al developed a novel marker, the nadir/baseline ratio, to have a high degree of association with a future course of immune reconstitution after HAART. They excluded subjects that never reached VL suppression or had an AIDS event after HAART. But it would be difficult to confirm this correlation between the new marker and the field immunological response in resource-limited settings. Patients in poor settings were often enrolled at an advanced stage of the disease in the treatment program, and confirmation of viral suppression was virtually impossible because of the unavailability of viral load in routine practice. In addition, the level of adherence varied greatly between patients. Their study was conducted in resource-rich settings with high rates of adherence in the cohort studied and access to early postinfection CD4 cell counts. They excluded subjects that never reached viral load suppression or had an AIDS event after HAART. Poor adherence is seriously affecting the long-term effectiveness of the current available treatments. ${ }^{56}$ Adherence is the key to a long-term benefit in these patients, who should be monitored and supported by a rigorous and rapid management of side effects. ${ }^{57}$

In the present study, adherence emerged as an important predictor of immunological response. Another study determined the relationship between adherence and immunovirological response and the results demonstrated the difficulties of adherence to ART in Abidjan. ${ }^{58}$ The problem of adherence is supported by a series of studies in Africa, ${ }^{59-64}$ in which the lowest rate was observed in Cote d'Ivoire. Indeed, Eholie et al found a low level of adherence in Ivorian patients and noted that adherence to HAART in Cote d'Ivoire is a more critical issue than previously reported. ${ }^{64}$ It is important to optimize adherence because it is essential to successful treatment. Age at initiation of therapy and the baseline clinical state did not have significant influence on ART immunological response at different periods of monitoring in Abidjan. Lifson et al analyzed the CD4 count trajectory after HAART initiation and showed that multiple factors may influence this immunological response, including a preceding AIDS diagnosis. ${ }^{65}$ But their study was related to the long-term CD4 count response. As in the present study, where an age limit of $>50$ years and another dealing with younger patients to assess the influence of age on ART response were considered, other authors also found that age was not a significant predictor of immunological response to ART in both the urban cohort in sub-Saharan Africa and in a United States cohort. ${ }^{37,66}$ In contrast, comparative studies in the United States showed an influence of age, with an average annual gain in CD4 cell count of $50 / \mathrm{mm}^{3}$ among subjects $\geq 50$ years against an average of $100 / \mathrm{mm}^{3}$ in the younger ones. ${ }^{67}$ Studies have also shown that an age of $>30$ years was associated with a suboptimal CD4 cell gain ${ }^{36,68}$ because it is correlated with the evolution of the thymus, which is necessary for adequate immune reconstitution. ${ }^{68,69}$ In general, studies have shown that the immunological response, closely linked to the regenerative capacity of the thymus, is less pronounced among the elderly receiving $A R T .{ }^{21,70,71}$ And the positive effect of young age on immune reconstitution has been repeatedly documented in studies of large cohorts. ${ }^{7,72-76}$

\section{Conclusion}

Among the predictors identified during ART, age and baseline clinical state did not have significant influence on immunological response in terms of CD4 cell gain in the present study. Baseline CD4 cell count and adherence influenced to varying degrees this immunological response. Patients in Cote d'Ivoire beginning treatment with a relatively low baseline CD4 cell count can achieve the optimal CD4 cell gain during the first 24 months of follow up with good adherence. Even if it is less likely for patients with a higher baseline CD4 cell count to obtain the optimal CD4 cell gain, maintaining relatively high CD4 cell counts during HAART is also possible with good adherence. The strength of the relationship between adherence and CD4 cell response was the most significant compared to that of baseline CD4 cell count during 24 months of ART in Abidjan (obtaining the optimal CD4 cell gain is almost six times higher among adherent patients when compared to a suboptimal gain of CD4 cells). Counseling before initiation of ART and therapeutic education during follow-up must always help to strengthen adherence and optimize the efficiency of ART in resource-limited settings.

\section{Disclosure}

The authors report no conflicts of interest in this work.

\section{References}

1. Joint United Nations Program on HIV/AIDS. Global report: UNAIDS report on the global AIDS epidemic 2010. November 2010. Available from: http://www.unaids.org/documents/20101123_GlobalReport_ Foreword_em.pdf. Accessed February 23, 2012.

2. Gadelha AJ, Accacio N, Costa RL, et al. Morbidity and survival in advanced AIDS in Rio de Janeiro, Brazil. Rev Inst Med Trop Sao Paulo. 2002;44(4):179-186. 
3. World Health Organization. Antiretroviral therapy for HIV infection in adults and adolescents: recommendations for a public health approach (2006 revision). 2006. Available from: http://www.who.int/hiv/pub/ guidelines/artadultguidelines.pdf. Accessed February 23, 2012.

4. Yeni P. 2008 report of the expert group on the medical management of people infected with HIV: recommendations. August 19, 2008. Available from: http://www.sante.gouv.fr/rapport-du-groupe-d-experts-2008-surla-prise-en-charge-medicale-des-patients-infectees-par-le-vih-sousla-direction-du-pr-patrick-yeni.html. Accessed February 23, 2012. French.

5. Dray-Spira R, Spire B, Heard I, Lert F. Heterogeneous response to HAART across a diverse population of people living with HIV: results from the ANRS-EN12-VESPA Study. AIDS. 2007;21 Suppl 1:S5-S12.

6. Department of Health and Human Services Panel on Antiretroviral Guidelines for Adults and Adolescents. Guidelines for the use of antiretroviral agents in HIV-1-infected adults and adolescents. December 1, 2009. Available from: http://s-cap.org/documents/GuidlinesforAntiretrovialTher apy12-11-09.pdf. Accessed February 23, 2012.

7. Kaufmann GR, Perrin L, Pantaleo G, et al. CD4 T-lymphocyte recovery in individuals with advanced HIV-1 infection receiving potent antiretroviral therapy for 4 years: the Swiss HIV Cohort Study. Arch Intern Med. 2003;163(18):2187-2195.

8. Moore RD, Keruly JC, Gebo KA, Lucas GM. An improvement in virologic response to highly active antiretroviral therapy in clinical practice from 1996 through 2002. J Acquir Immune Defic Syndr. 2005;39(2): 195-198.

9. Garcia F, de Lazzari E, Plana M, et al. Long-term CD4+ T-cell response to highly active antiretroviral therapy according to baseline CD4+T-cell count. J Acquir Immune Defic Syndr. 2004;36(2):702-713.

10. Egger M, May M, Chene G, et al. Prognosis of HIV-1-infected patients starting highly active antiretroviral therapy: a collaborative analysis of prospective studies. Lancet. 2002;360(9327):119-129.

11. Teerawattananon $Y$, Hanshaoworakul W, Russell S, Tangcharoensathien V, Jiamton S. Targeting antiretroviral therapy: lessons from a longitudinal study of morbidity and treatment in relation to CD4 count in Thailand. Asia Pac J Public Health. 2006;18(1):39-48.

12. Wood E, Hogg RS, Harrigan PR, Montaner JSG. When to initiate antiretroviral therapy in HIV-1-infected adults: a review for clinicians and patients. Lancet Infect Dis. 2005;5(7):407-414.

13. Hogg RS, Yip B, Chan KJ, et al. Rates of disease progression by baseline CD4 cell count and viral load after initiating triple-drug therapy. JAMA. 2001;286(20):2568-2577.

14. Sterne JA, May M, Costagliola D, et al. Timing of initiation of antiretroviral therapy in AIDS-free HIV-1-infected patients: a collaborative analysis of 18 HIV cohort studies. Lancet. 2009;373(9672):1352-1363.

15. Baker JV, Peng G, Rapkin J, et al. CD4+ count and risk of non-AIDS diseases following initial treatment for HIV infection. AIDS. 2008;22(7): 841-848.

16. Palella FJ Jr, Deloria-Knoll M, Chmiel JS, et al. Survival benefit of initiating antiretroviral therapy in HIV-infected persons in different CD4+ cell strata. Ann Intern Med. 2003;138(8):620-626.

17. Cameron DW, Heath-Chiozzi M, Danner S, et al; Advanced HIV Disease Ritonavir Study Group. Randomised placebo-controlled trial of ritonavir in advanced HIV-1 disease. Lancet. 1998;351(9102):543-549.

18. Bangsberg DR, Hecht FM, Charlebois ED, et al. Adherence to protease inhibitors, HIV-1 viral load and development of drug resistance in an indigent population. AIDS. 2000;14(4):357-366.

19. Weidle PJ, Malamba S, Mwebaze R, et al. Assessment of a pilot antiretroviral drug therapy programme in Uganda: patients' response, survival, and drug resistance. Lancet. 2002;360(9326):34-40.

20. Amico KR, Harman JJ, Johnson BT. Efficacy of antiretroviral therapy adherence interventions: a research synthesis of trials, 1996 to 2004. J Acquir Immune Defic Syndr. 2006;41(3):285-297.

21. Grabar S, Kousignian I, Sobel A, et al. Immunologic and clinical responses to highly active antiretroviral therapy over 50 years of age. Results from the French Hospital Database on HIV. AIDS. 2004;18(15): 2029-2038.
22. Abrogoua DP, Aulagner G, Kablan BJ, Petit C. Study of meta-trajectories of CD4 cells count from taxonomy in the antiretroviral response of efavirenz-based regimen with naive symptomatic patients in Abidjan. Ann Pharm Fr. 2011;69(1):7-21. French.

23. Abrogoua DP, Kablan BJ, Aulagner G, Petit C. Modeling of antiretroviral response from taxonomy of CD4 cells count trajectories in profound immunodeficiency setting. Therapie. 2011;66(3):247-261. French.

24. Abrogoua DP, Kablan BJ, Aulagner G, Petit C. Modeling of nevirapine-based antiretroviral regimen response by taxonomy from different CD4 cell counts strata. Afr J Pharm Pharmacol. 2011;5(7): 930-942.

25. Tan R, Westfall AO, Willig JH, et al. Clinical outcome of HIV-infected antiretroviral-naive patients with discordant immunologic and virologic responses to highly active antiretroviral therapy. JAcquir Immune Defic Syndr. 2008;47(5):553-558.

26. van Griensven J, Zachariah R, Rasschaert F, Reid T. Discordant immunologic and virologic responses to antiretroviral therapy and associated mortality in a large treatment program in Rwanda. J Acquir Immune Defic Syndr. 2009;50(5):556-558.

27. Moore DM, Hogg RS, Chan K, Tyndall M, Yip B, Montaner JS Disease progression in patients with virological suppression in response to HAART is associated with the degree of immunological response. AIDS. 2006;20(3):371-377.

28. Moore DM, Hogg RS, Yip B, et al. Discordant immunologic and virologic responses to highly active antiretroviral therapy are associated with increased mortality and poor adherence to therapy. J Acquir Immune Defic Syndr. 2005;40(3):288-293.

29. Achhra AC, Amin J, Law MG, et al. Immunodeficiency and the risk of serious clinical endpoints in a well studied cohort of treated HIVinfected patients. AIDS. 2010;24(12):1877-1886.

30. Centers for Disease Control and Prevention. 1993 revised classification system for HIV infection and expanded surveillance case definition for AIDS among adolescents and adults. MMWR Recomm Rep. 1992;41:(RR-17):1-19.

31. Eholie SP, Girard PM. Therapeutic memento of HIV/AIDS in Africa. Paris, France: Doin; 2005. French.

32. Eholie SP, Tanon KA, Folquet-Amorissani M, et al. Impact of access to antiretroviral therapy in Cote d'Ivoire. Med Trop (Mars). 2009;69(5):520-524. French.

33. Wolbers M, Battegay M, Hirschel B, et al. CD4+ T-cell count increase in HIV-1-infected patients with suppressed viral load within 1 year after start of antiretroviral therapy. Antivir Ther. 2007;12(6):889-897.

34. Le Moing V, Thiebaut R, Chene G, et al. Predictors of long-term increase in CD4(+) cell counts in human immunodeficiency virusinfected patients receiving a protease inhibitor containing antiretroviral regimen. J Infect Dis. 2002;185(4):471-480.

35. Tarwater PM, Margolick JB, Jin J, et al. Increase and plateau of CD4 T-cell counts in the 3(1/2) years after initiation of potent antiretroviral therapy. J Acquir Immune Defic Syndr. 2001;27(2):168-175.

36. Lawn SD, Myer L, Bekker LG, Wood R. CD4 cell count recovery among HIV-infected patients with very advanced immunodeficiency commencing antiretroviral treatment in sub-Saharan Africa. BMC Infect Dis. 2006;6:59.

37. Nakanjako D, Kiragga A, Ibrahim F, Castelnuovo B, Kamya MR, Easterbrook PJ. Sub-optimal CD4 reconstitution despite viral suppression in an urban cohort on antiretroviral therapy (ART) in sub-Saharan Africa: frequency and clinical significance. AIDS Res Ther. 2008;5:23-31.

38. Kitahata M, Dillingham P, van Rompaey S. Initiating potent combination antiretroviral therapy within 1 year of the first clinic visit for patients at all CD4 cell count levels is associated with better longterm outcomes. Paper presented at: 9th Conference on Retroviruses and Opportunistic Infections; February 24-28, 2002; Seattle, WA. Poster 467.

39. Sterne JA, Hernan MA, Ledergerber B, et al. Long-term effectiveness of potent antiretroviral therapy in preventing AIDS and death: a prospective cohort study. Lancet. 2005;366(9483):378-384. 
40. Lawn SD, Myer L, Orrell C, Bekker LG, Wood R. Early mortality among adults accessing a community-based antiretroviral service in South Africa: implications for programme design. AIDS. 2005;19(18): 2141-2148.

41. Moore RD, Keruly JC. CD4+ cell count 6 years after commencement of highly active antiretroviral therapy in persons with sustained virologic suppression. Clin Infect Dis. 2007;44(3):441-446.

42. Grabar S, Le Moing V, Goujard C, et al. Clinical outcome of patients with HIV-1 infection according to immunologic and virologic response after 6 months of highly active antiretroviral therapy. Ann Intern Med. 2000;133(6):401-410.

43. Tuboi SH, Brinkhof MW, Egger M, et al. Discordant responses to potent antiretroviral treatment in previously naive HIV-1-infected adults initiating treatment in resource-constrained countries: the antiretroviral therapy in low-income countries (ART-LINC) collaboration. J Acquir Immune Defic Syndr. 2007;45(1):52-59.

44. Hazenberg MD, Otto SA, van Benthem BH, et al. Persistent immune activation in HIV-1 infection is associated with progression to AIDS. AIDS. 2003;17(13):1881-1888.

45. Eggena MP, Barugahare B, Okello M, et al. T cell activation in HIV-seropositive Ugandans: differential associations with viral load, CD4+ T cell depletion, and coinfection. J Infect Dis. 2005;191(5): 694-701.

46. Borkow G, Weisman Z, Leng Q, et al. Helminths, human immunodeficiency virus and tuberculosis. Scand J Infect Dis. 2001;33(8): $568-571$.

47. Delgado J, Heath KV, Yip B, et al. Highly active antiretroviral therapy: physician experience and enhanced adherence to prescription refill. Antivir Ther. 2003;8(5):471-478.

48. Singh N, Squier C, Sivek C, Wagener M, Nguyen MH, Yu VL. Determinants of compliance with antiretroviral therapy in patients with human immunodeficiency virus: prospective assessment with implications for enhancing compliance. AIDS Care. 1996;8(3):261-269.

49. Gordillo V, del Amo J, Soriano V, Gonzalez-Lahoz J. Sociodemographic and psychological variables influencing adherence to antiretroviral therapy. AIDS. 1999;13(13):1763-1769.

50. Haubrich RH, Little SJ, Currier JS, et al. The value of patient-reported adherence to antiretroviral therapy in predicting virologic and immunologic response. AIDS. 1999;13(9):1099-1107.

51. Dragsted UB, Mocroft A, Vella S, et al. Predictors of immunological failure after initial response to highly active antiretroviral therapy in HIV-1-infected adults: a EuroSIDA study. $J$ Infect Dis. 2004;190(1):148-155.

52. Deeks SG, Barbour JD, Grant RM, Martin JN. Duration and predictors of CD4 T-cell gains in patients who continue combination therapy despite detectable plasma viremia. AIDS. 2002;16(2):201-207.

53. Wu H, Connick E, Kuritzkes DR, et al. Multiple CD4+ cell kinetic patterns and their relationships with baseline factors and virological responses in HIV type 1 patients receiving highly active antiretroviral therapy. AIDS Res Hum Retroviruses. 2001;17(13):1231-1240.

54. Hill A, Montaner J, Lederman M, Cuttrell A, Tortell S, Thorborn D. Discordant CD4/RNA responses to HAART are strongly associated with high baseline CD4 count and low HIV RNA: analysis of 406 naive patients. Paper presented at: 3rd International Workshop on Drug Resistance and Treatment Strategies; June 23-26; San Diego, CA. Poster 152.

55. Kulkarni H, Okulicz JF, Grandits G, et al. Early postseroconversion CD4 cell counts independently predict CD4 cell count recovery in HIV-1postive subjects receiving antiretroviral therapy. J Acquir Immune Defic Syndr. 2011;57(5):387-395.

56. Montaner JS, Hogg R, Raboud J, Harrigan R, O'Shaughnessy M. Antiretroviral treatment in 1998. Lancet. 1998;352(9144):1919-1922.

57. Moreno A, Perez-Elias MJ, Casado JL, et al. Effectiveness and pitfalls of initial highly active antiretroviral therapy in HIV-infected patients in routine clinical practice. Antivir Ther. 2000;5(4):243-248.
58. Eholie SP. Analysis of adherence to antiretroviral therapy in Abidjan. Paper presented at: 13th International Conference of HIV/AIDS and Sexually Transmitted Infections in Africa; September 22-25, 2003; Nairobi, Kenya. Abstract 971451. French

59. Orrell C, Bangsberg DR, Badri M, Wood R. Adherence is not a barrier to successful antiretroviral therapy in South Africa. AIDS. 2003;17(9):1369-1375.

60. Tassie JM, Szumilin E, Calmy A, Goemaere E; Medecins Sans Frontieres. Highly active antiretroviral therapy in resource-poor settings: the experience of Medecins Sans Frontieres. AIDS. 2003;17(13):1995-1997.

61. Laniece I, Ciss M, Desclaux A, et al. Adherence to HAART and it principal determinants in a cohort of Senegalese adults. AIDS. 2003;17 Suppl 3:S103-S108.

62. Nachega JB, Stein DM, Lehman DA, et al. Adherence to antiretroviral therapy in HIV-infected adults in Soweto, South Africa. AIDS Res Hum Retroviruses. 2004;20(10):1053-1056.

63. Daniel OJ, Ogun SA, Odusoga OL, et al. Adherence pattern to ARV drugs among AIDS patients on self-purchased drugs and those on free medications in Sagamu, Nigeria. Paper presented at: The XV International AIDS Conference; March 30-April 2, 2004; Bangkok, Thailand. Abstract WePeB5768.

64. Eholie SP, Tanon A, Polneau S, et al. Field adherence to highly active antiretroviral therapy in HIV-infected adults in Abidjan, Cote d'Ivoire. J Acquir Immune Defic Syndr. 2007;45(3):355-358.

65. Lifson AR, Krantz EM, Eberly LE, et al. Long-term CD4+ lymphocyte response following HAART initiation in a US Military prospective cohort. AIDS Res Ther. 2011;8(1):2.

66. Patterson K, Napravnik S, Eron J, Keruly J, Moore R. Effects of age and sex on immunological and virological responses to initial highly active antiretroviral therapy. HIV Med. 2007;8(6):406-410.

67. Perez JL, Moore RD. Greater effect of highly active antiretroviral therapy on survival in people aged $\geq 50$ years compared with younger people in an urban observational cohort. Clin Infect Dis. 2003;36(2): 212-218.

68. Teixeira L, Valdez H, McCune JM, et al. Poor CD4 T cell restoration after suppression of HIV-1 replication may reflect lower thymic function. AIDS. 2001;15(14):1749-1756.

69. Aiuti F, Mezzaroma I. Failure to reconstitute CD4+ T-cells despite suppression of HIV replication under HAART. AIDS Rev. 2006;8(2): $88-97$.

70. Douek DC, McFarland RD, Keiser PH, et al. Changes in thymic function with age and during the treatment of HIV infection. Nature. 1998;396(6712):690-695.

71. Franco JM, Rubio A, Martinez-Moya M, et al. T-cell repopulation and thymic volume in HIV-1-infected adult patients after highly active antiretroviral therapy. Blood. 2002;99(10):3702-3706.

72. Hunt PW, Deeks SG, Rodriguez B, et al. Continued CD4 cell count increases in HIV-infected adults experiencing 4 years of viral suppression on antiretroviral therapy. AIDS. 2003;17(13):1907-1915.

73. Kaufmann GR, Furrer H, Ledergerber B, et al. Characteristics, determinants, and clinical relevance of CD $4 \mathrm{~T}$ cell recovery to $<500$ cells $/ \mu \mathrm{L}$ in HIV type 1-infected individuals receiving potent antiretroviral therapy. Clin Infect Dis. 2005;41(3):361-372.

74. Mocroft A, Phillips AN, Ledergerber B, et al. Relationship between antiretrovirals used as part of a cART regimen and CD4 cell count increases in patients with suppressed viremia. AIDS. 2006;20(8): $1141-1150$.

75. Le Moing V, Thiebaut R, Chene G, et al. Long-term evolution of CD4 count in patients treated with a plasma HIV RNA persistently $<500$ copies $/ \mathrm{mL}$ during treatment with antiretroviral drugs. HIV Med. 2007;8(3):156-163.

76. Viard JP, Mocroft A, Chiesi A, et al. Influence of age on CD4 cell recovery in human immunodeficiency virus-infected patients receiving highly active antiretroviral therapy: evidence from the EuroSIDA study. J Infect Dis. 2001;183(8):1290-1294. 
Patient Preference and Adherence

Dovepress

\section{Publish your work in this journal}

Patient Preference and Adherence is an international, peer-reviewed, open access journal focusing on the growing importance of patient preference and adherence throughout the therapeutic continuum. Patient satisfaction, acceptability, quality of life, compliance, persistence and their role in developing new therapeutic modalities and compounds to optimize clinical outcomes for existing disease states are major areas of interest. This journal has been accepted for indexing on PubMed Central. The manuscript management system is completely online and includes a very quick and fair peer-review system. Visit http://www.dovepress.com/ testimonials.php to read real quotes from published authors.

Submit your manuscript here: http://www.dovepress.com/patient-preference-and-adherence-journal 